\title{
Histomorphological studies of the liver of Plasmodium-infected albino mice after administration of aqueous leaf extract of Mangifera indica (Linn.)
}

\author{
Ahmed A. Olayode ${ }^{1}$, David A. Ofusori ${ }^{1}$, Titus A. B. Ogunniyi ${ }^{2}$, Olusola S. Saka ${ }^{1}$ \\ ${ }^{1}$ Department of Anatomy and Cell Biology, Faculty of Basic Medical Sciences, Obafemi Awolowo University, Ile-Ife, Nigeria \\ ${ }^{2}$ Department of Medical Microbiology and Parasitology, Faculty of Basic Medical Sciences, Obafemi Awolowo University, Ile-Ife, Nigeria
}

\begin{abstract}
Objectives: This study was carried out to assess the histomorphological findings of the liver of Plasmodium-infected albino mice following administration of aqueous leaf extract of Mangifera indica.

Methods: Forty-two male albino mice, weighing 20-25 g, were used for this research. The mice were randomly assigned into six groups $A, B, C, D, E$ and $F(n=7$, each). Groups $B, C, D, E$ and $F$ were infected with $P$. berghei, while group $A$ was administered equivalent volume of normal saline. Mice in groups $C, D$ and $E$ were orally administered Mangifera indica extract (50 mg/kg, $100 \mathrm{mg} / \mathrm{kg}$ and $150 \mathrm{mg} / \mathrm{kg}$ body weight, respectively) dissolved in $0.2 \mathrm{ml}$ of distilled water for 5 days, and those in group $F$ were orally administered with artesunate for 5 days $(3 \mathrm{mg} / \mathrm{kg}$ and $1.5 \mathrm{mg} / \mathrm{kg}$ body weight on the first day and on subsequent 4 days, respectively) while groups $A$ and B were administered equivalent volume of distilled water, all administrations starting 72 hours post-infection. The animals were left for another 14 days after treatment.

Results: The result showed that the extract treated groups presented dose dependent ameliorative changes in the organization of histoarchitecture such as reduction of collagen fibers, reticular fibers and hemozoins. There was a significant decrease $(p<0.0001)$ in the percentage parasitemia in groups $C, D$ and $E$ when compared with group $B$. There was also a significant $(p<0.03)$ reduction in Kupffer cell density in groups $C, D$ and $E$ when compared with group B.
\end{abstract}

Conclusion: This study showed that Mangifera indica has an ameliorative effect against injury-related changes in liver histomorphology.

Keywords: histomorphology; liver; Mangifera indica; mouse; Plasmodium berghei

Anatomy 2015;9(3):168-176 @2015 Turkish Society of Anatomy and Clinical Anatomy (TSACA)

\section{Introduction}

Malaria, the world's most devastating human parasitic infection, ${ }^{[1]}$ is a vector-borne infectious disease which is caused by various single celled protozoans of the genus Plasmodium. Human malaria is transmitted by female Anopheles mosquitoes. ${ }^{[2]}$

Most serious illnesses and deaths are attributed to Plasmodium (P.) falciparum which causes fevers that sometimes occur at less than 48-hour intervals. Symptoms like high fever, headache, drowsiness and confusion occur as the parasites spread to several other organs to cause other symptoms like jaundice, diarrhea and kidney failure. Malarial parasites have developed resistance to a number of anti-malarial medicines in many parts of the world..$^{[2]}$ Prompt and effective treatment with artemisinin-based combination therapies, usage of mosquito nets or insecticidal nets by people at risk, and indoor residual spraying of insecticide to control the mosquito vectors are important for elimination and control of malaria. ${ }^{[3]}$ 
The four Plasmodium species that have been described in African murine rodents are P. berghei, $P$. chabaudi, $P$. vinckei and $P$. yoelli. $P$. berghei infects the liver after being injected into the bloodstream by a bite of an infected female mosquito. Plasmodium species is used for development and screening of anti-malarial drugs and the development of an effective vaccine against malaria, since it has the same effects on rodents as $P$. falciparum ${ }^{[4,5]}$

Multiplication of the parasite in the blood causes anemia and damage of essential organs of the host such as the lungs, liver and spleen. $P$. berghei infections may also affect the brain causing cerebral complications in laboratory mice with symptoms comparable to those of patients infected with $P$. falciparum. ${ }^{[4,5]}$

Disrupting the life cycle of the parasite by controlling the vector had only limited success, while the anti-malarial drugs are not easily available to those most in need and there has also been rapid evolution of drug resistant parasites. ${ }^{[6]}$ Therefore, an effective vaccine is the most promising approach to controlling the disease, but it is still not available.

Several malarial syndromes including severe anaemia, hyperparasitemia, cerebral malaria, acute respiratory distress and chemical jaundice differ significantly in terms of target organs of disease, with the brain, lungs, kidney and liver affected. ${ }^{[7]}$ The common feature of all severe malaria syndromes is that parasite burdens are significantly higher than in patients suffering uncomplicated malaria; ${ }^{[8]}$ parasite burdens play a crucial role in causing cerebral, respiratory and hepatic pathologies during malaria.

Initial manifestations of disease for all malaria species can resemble flu symptoms, ${ }^{[9]}$ and other conditions such as septicemia, gastroenteritis, and viral diseases. ${ }^{[10]}$ Splenomegaly, hepatomegaly, hypoglycemia, severe headache, and hemoglobinuria with renal failure may occur. ${ }^{[9]}$ Toxicity, such as fatal neuropenia by amodiaquine ${ }^{[1]]}$ reversible retinopathy by chloroquine, ${ }^{[12]}$ exfoliative dermatitis and aplastic anaemia by mepacrine, ${ }^{[13]}$ and acute brain syndrome presenting with convulsions by mefloquine $^{[14]}$ are known to be associated with conventional anti-malarial drugs.

The infection of liver cells by sporozoites form of the malaria parasite can cause organ congestion, sinusoidal blockage and cellular inflammation. Liver changes in severe malaria often include hyperplastic Kupffer cells, ${ }^{[15,16]}$ fatty changes, portal tract inflammation, cholestasis ${ }^{[17]}$ liver cell necrosis, ${ }^{[15]}$ sequestration of parasitized red blood cells (PRBCs) and the deposition of hemozoin pigment. ${ }^{[16,18]}$ Histopathological changes in the livers of severe P. falciparum malaria cases are associated with increase in total bilirubin levels. ${ }^{[19]}$ Hepatomegaly occurs as a result of inflammation and accumulation of cytotoxic substances and white blood cells. ${ }^{[20]}$
Mangifera indica Linn (MI) is a species of mango in the Anacardiaceae family, one of the most important tropical plants marketed in the world. ${ }^{[2]]}$ It is found in the wild in India and cultivated varieties have been introduced to other warm regions of the world, including Nigeria. The different chemical constituents of the plant are the polyphenolics, flavonoids, triterpenoids and mangiferin (a xanthone glycoside is its major bio-active constituent), isomangiferin, tannins and gallic acid derivatives. ${ }^{[2]}$

Oyewo et al. ${ }^{[23]}$ stated that administration of Mangifera indica extract showed no mortality and toxic effect on the histoarchitecture of the liver in adult Wistar rats. This study was thus performed to examine the histomorphology of the liver of Plasmodium-infected mice following administration of aqueous leaf extract of Mangifera indica.

\section{Materials and Methods \\ Animal care and management}

Forty-two male albino mice (Mus musculus), weighing between 20 and $25 \mathrm{~g}$, obtained from the Animal holding of College of Health Sciences, Obafemi Awolowo University Ile-Ife, were used for this research. The mice were housed in plastic cages in the Animal Holding of the Department of Anatomy and Cell Biology, Obafemi Awolowo University Ile-Ife. They were maintained on standard laboratory animal pellets before the start of the experiment and water was provided ad libitum. The mice were randomly assigned into six groupsA, B, C, D, E and F of seven mice each.

\section{Plant material and preparation of extract}

Fresh leaves of mango tree were obtained from plantations in Ile-Ife and authenticated by a plant taxonomist in the Department of Botany, Obafemi Awolowo University, IleIfe. A voucher specimen was deposited at the department's Herbarium for future reference (Voucher number: IFE17465). The leaves were washed with clean water and airdried. The dried leaves were pulverized with squeezing and crushing machine (Daiki Rika Kogyo Co., Ltd., Kounosu, Saitama, Japan) into fine powder. The aqueous extract was prepared by extracting the powdered leaves, weighing 2.0 $\mathrm{kg}$, with $6 \mathrm{~L}$ of distilled water, macerated in a polytron homogenizer for 48 hours and the solution was filtered using Buchner funnel and Whatmann No. 1 filter paper (Whatmann International Ltd, Maidstone, UK). The filtrate was evaporated under $56 \mathrm{~atm}$ reduced pressure using a rotary evaporator (Rotavapor-R110, Büchi Labortechnik, Flawil, Switzerland) and later freeze-dried in a lyophilizer (Ilshin Lab. Co. Ltd, Seoul, Republic of Korea). The extract obtained was kept in a desiccator until use. The percentage yield was $10.52 \%$. 


\section{Infection with Plasmodium parasites}

Infection with Plasmodium parasites was done in the Department of Medical Microbiology and Parasitology, College of Health Sciences, Obafemi Awolowo University, Ile-Ife. Mice were infected with $P$. berghei intraperitoneally with $0.2 \mathrm{ml}$ of mixture of infected blood of the donor mouse whose parasitemia level was approximately $36 \%$ and normal saline at ratio $1: 31$, respectively. The infection was carried out on the first day of the research and left for two more days to allow for the spread of Plasmodium parasites. ${ }^{[2]]}$ The percentage parasitemia was determined on the 3rd day to confirm the Plasmodium status of each mouse. The animal handling and care was in line with the rules and guideline of the Health Research and Ethics Committee of the Institute of Public Health, Obafemi Awolowo University Ile-Ife, Nigeria.

\section{Experimental design}

- Group A was the negative control group administered equivalent volume of normal saline;

- Group B was infected with Plasmodium parasite (PP) + equivalent volume of normal saline;

- Group C was infected with PP and treated with MI (50 mg/kg body weight) after 72 hours post-infection for 5 days;

- Group D was infected with PP and treated with MI (100 mg/kg body weight) after 72 hours post - infection for 5 days;

- Group E was infected with PP and treated with MI (150 mg/kg body weight) after 72 hours post-infection for 5 days; and

- Group F was infected with PP and treated with artesunate after 72 hours post-infection for 5 days (3 $\mathrm{mg} / \mathrm{kg}$ body weight on first day and $1.5 \mathrm{mg} / \mathrm{kg}$ body weight for the next 4 days).

The animals were left for another 14 days after treatment during which percentage parasitemia was calculated from blood smear every other day. The mice were weighed during the experimental period.

\section{Sacrifice of animals and histological analyses}

At the end of the experiment, the mice in all groups were sacrificed under chloroform anaesthesia. After sacrifice, the liver was removed and processed histologically for microscopic examination. The excised livers were fixed in $10 \%$ formol saline for minimum of 72 hours, and processed using paraffin wax embedding method. Paraffin embedded tissues were cut at a thickness of $5 \mu \mathrm{m}$ and stained with haematoxylin and eosin (H\&E). Masson's trichrome stain was used to demonstrate collagen fibers, and Gordon and Sweets' silver impregnation method was used to demonstrate reticular fibers. Liver sections stained with Giemsa were examined to confirm the presence of Plasmodium parasite under the oil immersion lens of Leica DM750 microscope.

Stained sections were viewed under a Leica DM750 microscope (Leica Microsystems GmbH, Wetzlar, Germany) with a Leica ICC50 digital camera (Leica Camera AG, Wetzlar, Germany) attached, and digital photomicrographs were taken at various magnifications.

\section{Statistical analysis}

One-way ANOVA was used to analyze data, followed by Student Newman-Keuls (SNK) test for multiple comparisons. Significant difference was set at $\mathrm{p}<0.05$.

\section{Results}

\section{Body weights of control and treated mice}

There was a gradual increase in body weight of mice in the negative control, $150 \mathrm{mg} / \mathrm{kg}$ MI and artesunate groups (Figure 1). There was a gradual decrease in mean body weights of group B $(20.30 \pm 0.45 \mathrm{~g}, 18.30 \pm 0.30 \mathrm{~g}$ and $17.50 \pm$ $0.33 \mathrm{~g}$ ) on days 8,15 and 22 when compared across groups C $(22.10 \pm 0.33 \mathrm{~g}, 22.50 \pm 0.36 \mathrm{~g}$ and $22.80 \pm 0.35 \mathrm{~g}), \mathrm{D}$ $(22.50 \pm 0.29 \mathrm{~g}, 22.70 \pm 0.47 \mathrm{~g}$ and $22.70 \pm 0.64 \mathrm{~g}), \mathrm{E}(23.00 \pm$ $0.38 \mathrm{~g}, 23.20 \pm 0.36 \mathrm{~g}$ and $23.50 \pm 0.40 \mathrm{~g})$ and $\mathrm{F}(24.60 \pm 0.29$ $\mathrm{g}, 24.90 \pm 0.32 \mathrm{~g}$ and $25.70 \pm 0.44 \mathrm{~g})$, respectively. There were significant differences $(\mathrm{p}<0.0001)$ between groups $\mathrm{F}$ $(24.60 \pm 0.29 \mathrm{~g}, 24.90 \pm 0.32 \mathrm{~g}$ and $25.70 \pm 0.44 \mathrm{~g})$ and $\mathrm{E}$ $(23.00 \pm 0.38 \mathrm{~g}, 23.20 \pm 0.36 \mathrm{~g}$ and $23.50 \pm 0.40 \mathrm{~g})$ on days 8 ,

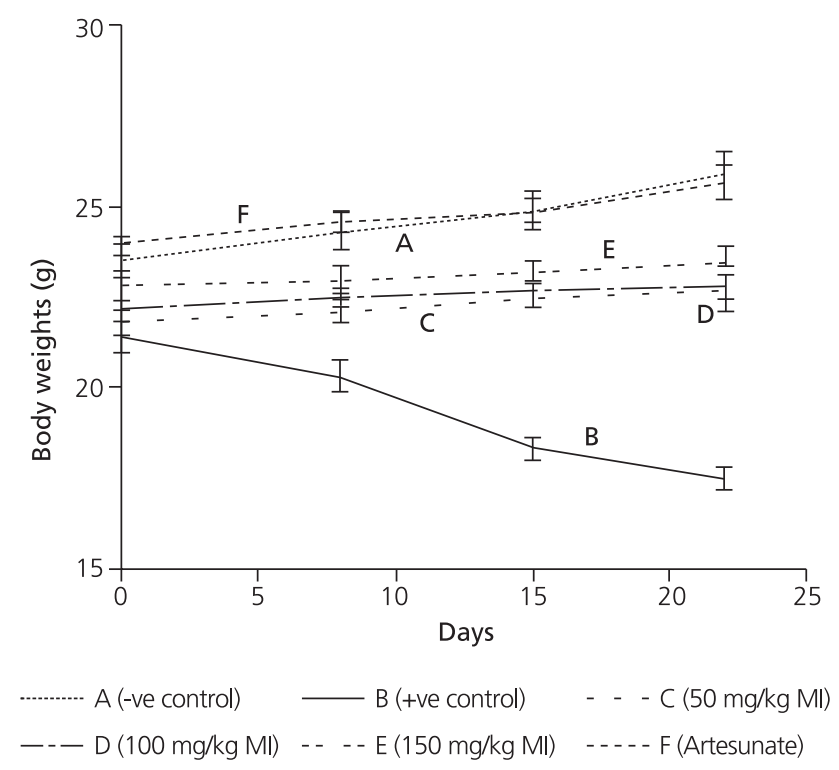

Figure 1. The effect of Mangifera indica and artesunate on the body weight of control and treated mice. 
15 and 22, respectively. A significant increase $(\mathrm{p}<0.0001)$ was found for in mean body weights of group A $(24.30 \pm 0.54 \mathrm{~g}, 24.90 \pm 0.55 \mathrm{~g}$ and $25.90 \pm 0.70 \mathrm{~g})$ when compared with group B $(20.30 \pm 0.45 \mathrm{~g}, 18.30 \pm 0.30 \mathrm{~g}$ and $17.50 \pm 0.33 \mathrm{~g}$ ) on days 8,15 and 22 , respectively.

\section{Level of parasitemia}

The result presented a significant decrease $(\mathrm{p}<0.0001)$ in the levels of parasitemia in groups C $(16.22 \pm 0.50 \%)$, D $(14.69 \pm 0.64 \%), \mathrm{E}(14.02 \pm 0.28 \%)$ and $\mathrm{F}(11.74 \pm 0.29 \%)$, when compared with group B $(33.80 \pm 0.94 \%)$. There was no significant change $(\mathrm{p}=0.3051)$ in the parasitemia levels between the treated groups (Figure 2).

\section{Kupffer cell density}

There was a significant increase in the Kupffer cell density in the positive control $(13.60 \pm 0.65)$ when compared with the treated groups as shown in Figure 3. There was also a dose-dependent decrement in Kupffer cell density of the extract treated groups.

\section{Histological findings}

\section{Haematoxylin and eosin staining}

The hepatic histoarchitecture of the control group presented parenchymal cells arranged in lobules. Each lobule appeared with a central vein at its centre and portal canals at the periphery. The portal triad comprised branches of the hepatic artery, hepatic vein and bile duct. The hepatic cells were arranged in series of branching plates between which are the sinusoidal plates (Figure 4a). Sections from the untreated Plasmodium-infected mice showed presence of inflammatory lymphocytes, increased number of Kupffer cells within the sinusoids, disruption of the normal structural organization of the hepatic lobules and loss of the characteristic radial arrangement of the normal liver cells (Figure 4b). Hepatocytic vacuolations, congested sinusoids and lymphocytes aggregating around the portal vein were noticed in the mice treated with $50 \mathrm{mg} / \mathrm{kg} \mathrm{MI}$ (Figure 4c). In Figure 4d, sinusoidal congestion, mild inflammation of the portal tracts, mixture of nuclei with normal and prominent nucleoli which are hyperchromatic and hepatocytic vacuolations were noticed in mice treated with $100 \mathrm{mg} / \mathrm{kg}$ MI. Following treatment with 150 $\mathrm{mg} / \mathrm{kg} \mathrm{MI}$, the sinusoids appeared less congested and more radially arranged with reduced number of Kupffer cells, borders of cytoplasm are not clearly defined; there was mild inflammation of the hepatocytes and lymphocyte aggregating around the portal tract (Figure 4e). Figure 4f also revealed congested sinusoids with prominent nucleoli within the nuclei of the hepatocytes around the central vein with presence of inflammatory lymphocytes.

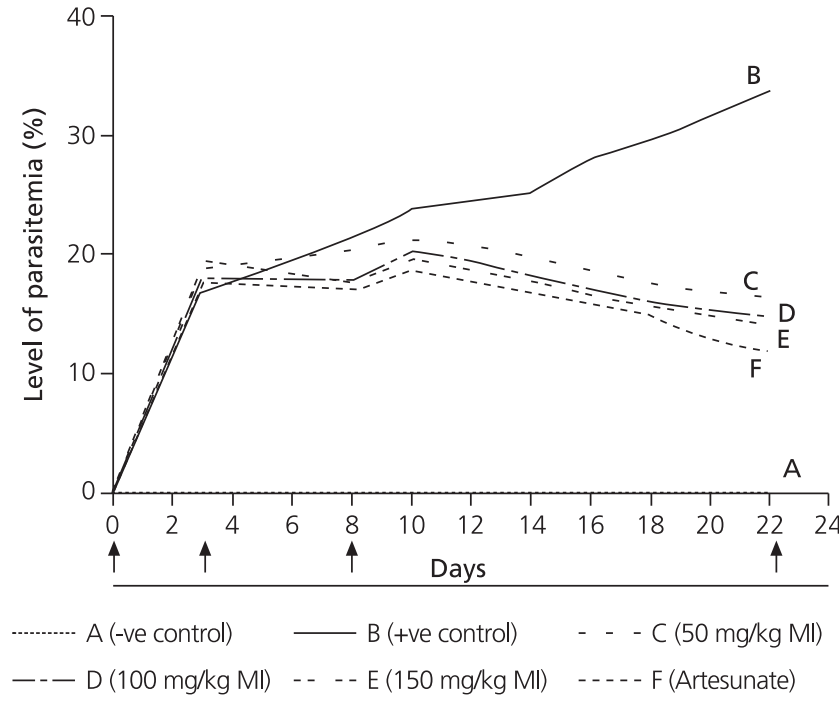

Figure 2. The effect of Mangifera indica and artesunate on the parasitemia level (\%) in control and treated mice. Arrows in order: inoculation of Plasmodium parasites; administration of $\mathrm{Ml}$ and artesunate started; administration of $\mathrm{Ml}$ and artesunate ended and beginning of 2week withdrawal period; 2-week withdrawal period ended.

\section{Gordon and Sweets' silver impregnation method}

There was regular distribution of the reticular fibers around the central vein and the lining of the sinusoids of the liver tissue in Figure 5a. The reticular fibers were observed to be sparsely distributed as shown in Figure 5b. In Figure 5c, the reticular fibers were less in distribution compared to Figure 5a. There wassparse distribution of the reticular fibers along the outline of the cen-

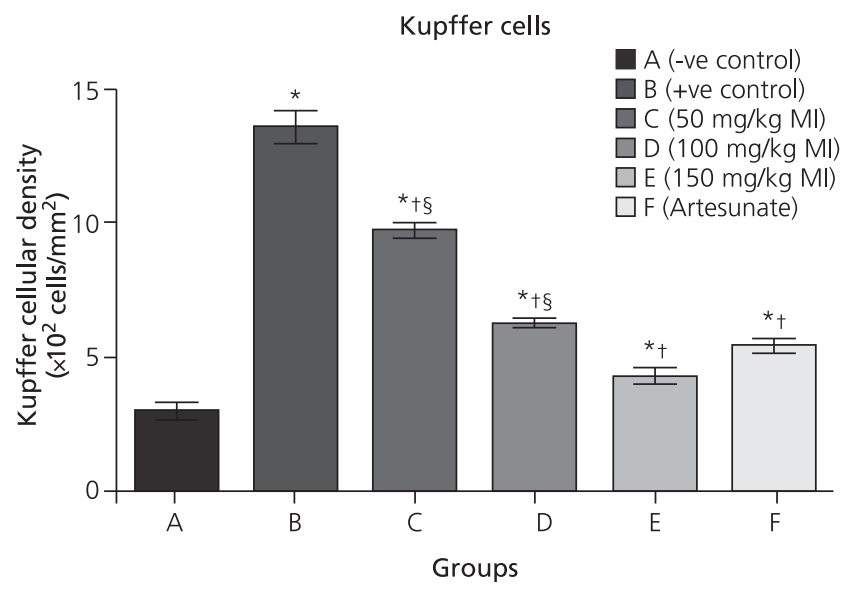

Figure 3. Kupffer cellular density $\left(\times 10^{2}\right.$ cells $\left./ \mathrm{mm}^{2}\right)$ in control and treated groups. Values are expressed as mean $\pm S E M ; p<0.05$. * significantly different when compared with group A (negative control); ‘ significantly different when compared with group B (positive control); §significantly different when compared with group $F$ (artesunate). 

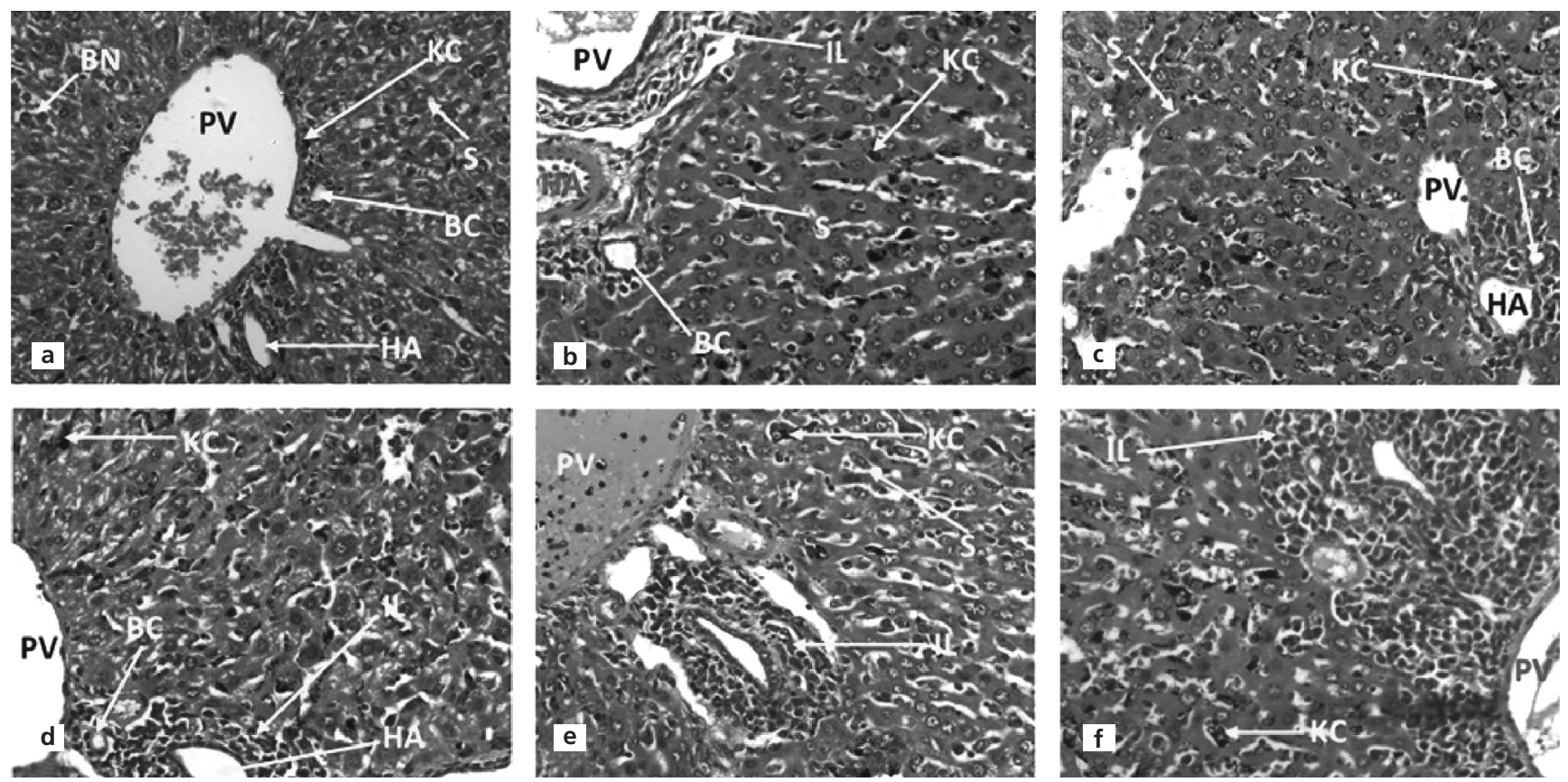

Figure 4. Photomicrographs of the liver with Haematoxylin and eosin stain ( $\times 400)$. Negative control (a), positive control (b), $50 \mathrm{mg} / \mathrm{kg} \mathrm{Ml}(\mathbf{c}), 100$ $\mathrm{mg} / \mathrm{kg} \mathrm{MI}(\mathbf{d}), 150 \mathrm{mg} / \mathrm{kg} \mathrm{MI}(\mathbf{e})$, and artesunate (f). BC: bile canalicula; BN: binucleated nuclei; HA: hepatic artery; IL: inflammatory lymphocyte; KC: Kupffer cell; PV: portal vein; S: sinusoid

tral vein and lining of the sinusoids (Figure 5d). Although, there are concentrations of reticular fibers (Figure 5e), this was not evenly distributed within the hepatic parenchyma. Sparse distribution of the reticular fibers around the central vein and lining the sinusoids was evident in Figure 5f.
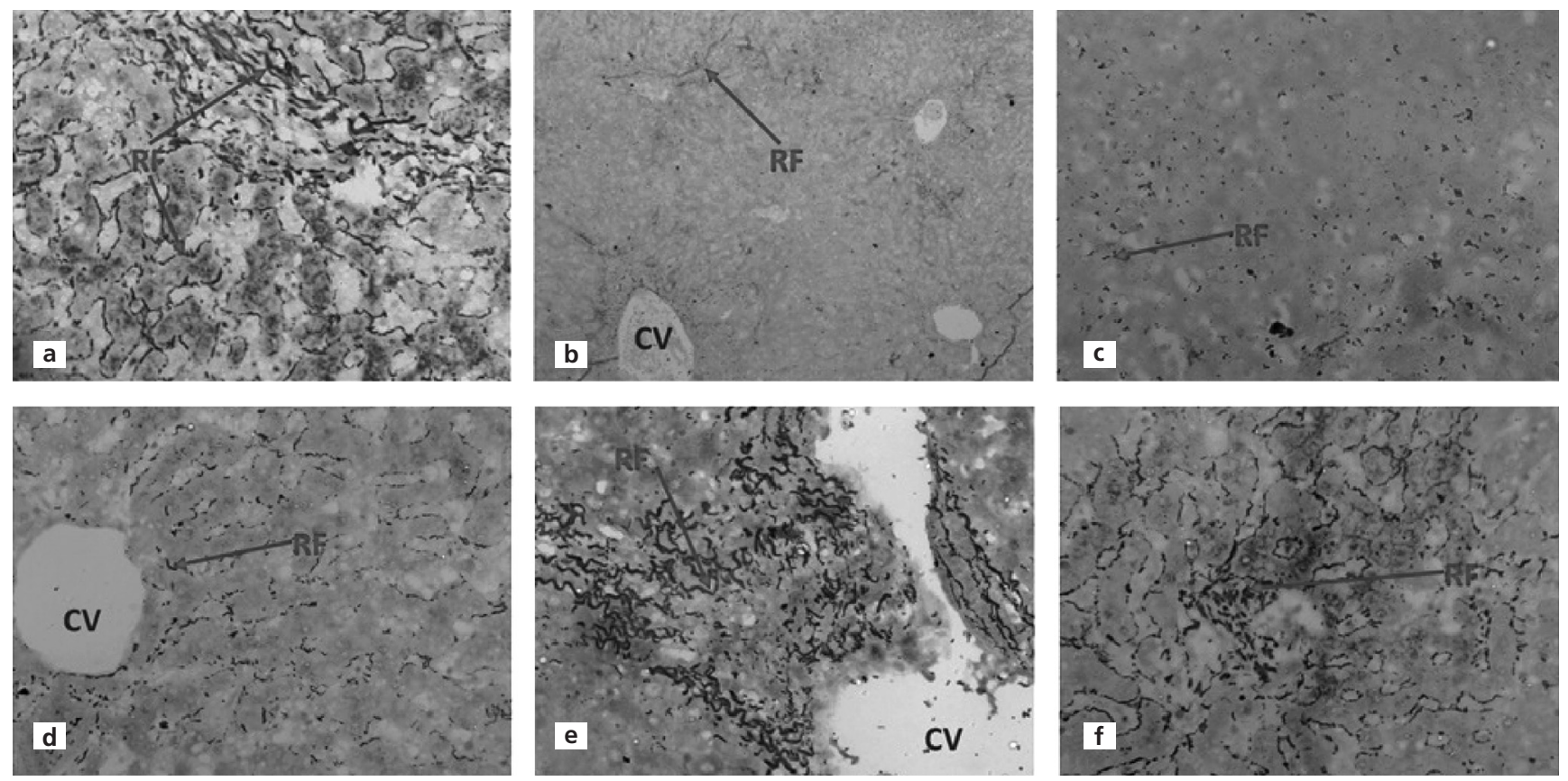

Figure 5. Photomicrographs of the liver stained with Gordon and Sweets' silver impregnation method ( $\times 400)$. Negative control (a), positive control (b), $50 \mathrm{mg} / \mathrm{kg} \mathrm{Ml} \mathrm{(c),} 100 \mathrm{mg} / \mathrm{kg} \mathrm{Ml}(\mathbf{d}), 150 \mathrm{mg} / \mathrm{kg} \mathrm{MI}(\mathbf{e})$, and artesunate (f). CV: central vein; RF: reticular fibers 

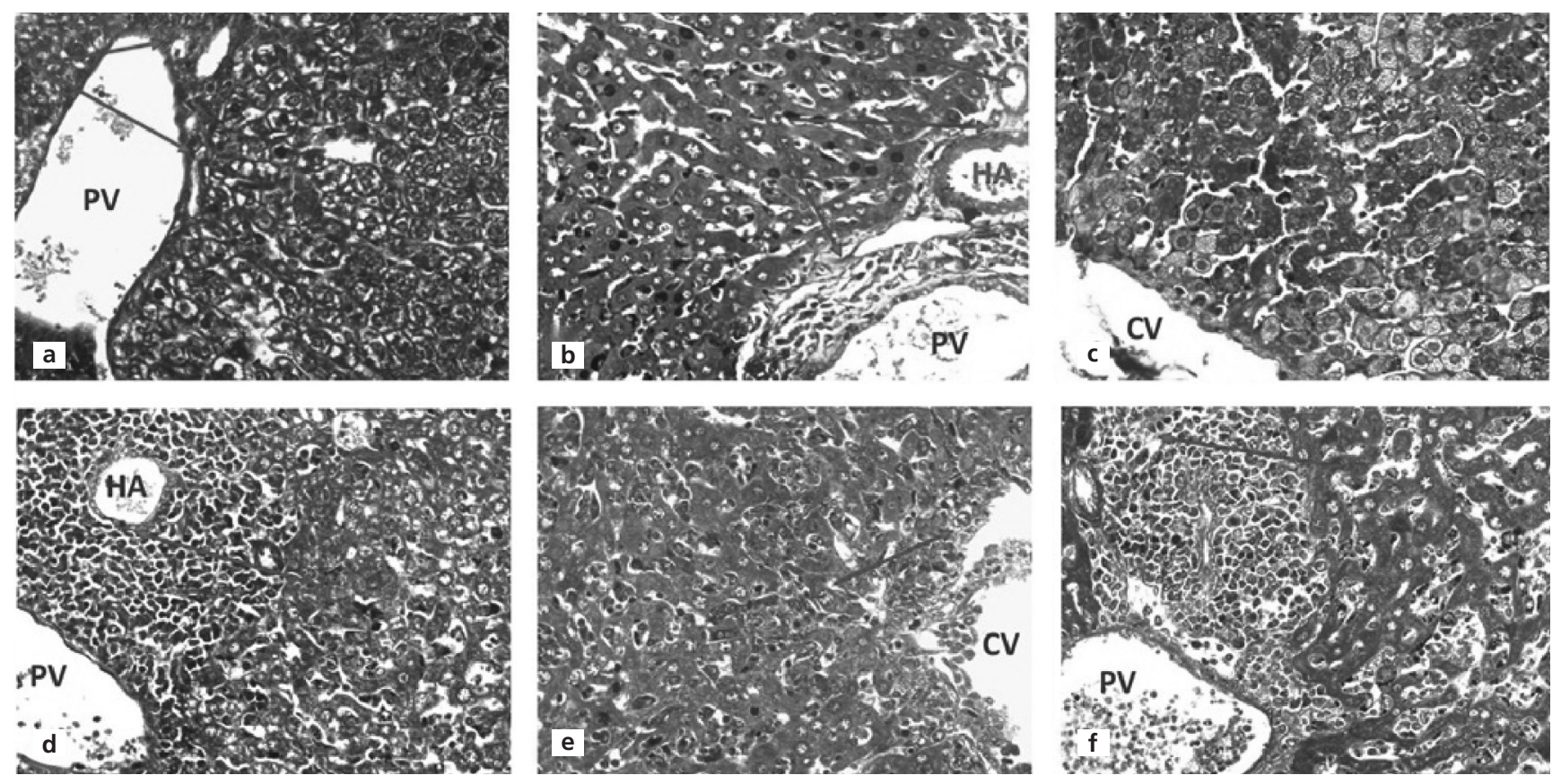

Figure 6. Photomicrographs of the liver stained with Masson's trichrome stain ( $\times 400)$. Negative control (a), positive control (b), $50 \mathrm{mg} / \mathrm{kg} \mathrm{Ml}(\mathbf{c}), 100$ $\mathrm{mg} / \mathrm{kg} \mathrm{MI}(\mathbf{d}), 150 \mathrm{mg} / \mathrm{kg} \mathrm{MI}$ (e), and artesunate (f). BC: bile canaliculum; C: collagen deposits; CV: central vein; HA: hepatic artery; PV: portal vein

\section{Masson's trichrome staining}

Normal histoarchitecture of liver tissue was evident with the sinusoids radially arranged. Also sparse distribution of collagen fibers was observed around the central vein (Figure 6a). Collagen deposition was found distributed around the portal triad and the sinusoids of the untreated group (Group B; Figure 6b). There was presence of collagen fibers around the central vein and within the sinusoids of animals in group C (Figure 6c). Collagen fibers of animals in group D showed similar pattern with that of control animals (Figure 6d). There was concentration of collagen fibers around the inflammatory lymphocytes more than within the sinusoids of animals in group E (Figure 6e). Deposition of collagen fibers around the inflammatory lymphocytes, the central vein and the sinusoids was evident for animals in group $\mathrm{F}$ (Figure 6f).

\section{Giemsa's staining}

The liver histoarchitecture revealed different degrees of hemozoins (Hz) (black spots) - parasite pigments density in the micrographs of the experimental mice. There was no deposition of parasitic pigmentation within the sinusoids (Figure 7a). Figure $\mathbf{7 b}$ revealed high density of hemozoins within the sinusoids of animals in group B. There was a dose dependent reduction in the hemozoins within the hepatic sinusoids of the extract treated mice
(Figures 7c-e). Animals in group F presented a similar pattern of hemozoins distribution when compared with animals in group E (Figures 7e, f).

\section{Discussion}

A gradual significant reductionwas observed in the body weight of $P$. berghei-infected mice left untreated which is in conformity with the study of Yeshanew and Mekonnen. ${ }^{[25]}$ There was a gradual increase in the body weights of the mice in the extract treated and artesunate groups. One of the features of rodent malaria infections is body weight loss. ${ }^{[26]}$ Nwinuka et al. ${ }^{[27]}$ reported a gradual increase in the body weight following the administration of extract of MI.These are in accordance with the findings in this study. The increase in weight may be due to MI inhibiting gluconeogenesis and eventually preventing the breakdown of fats stored in the body. This also conforms the findings of Sellamuthu et al. ${ }^{[28]}$

Our results also showed that the positive control group presented a gradual significant increase in parasitemia, while the levels of parasitemia in the treated groups were reduced significantly $(p<0.05)$ when compared with the positive control group. This significant reduction of percentage levels of parasitemia by MI was dose dependent. The presence of triterpenoid in MI might have inhibited the stages of infection, thereby reducing the percentage parasitemia. Triterpenoid pos- 

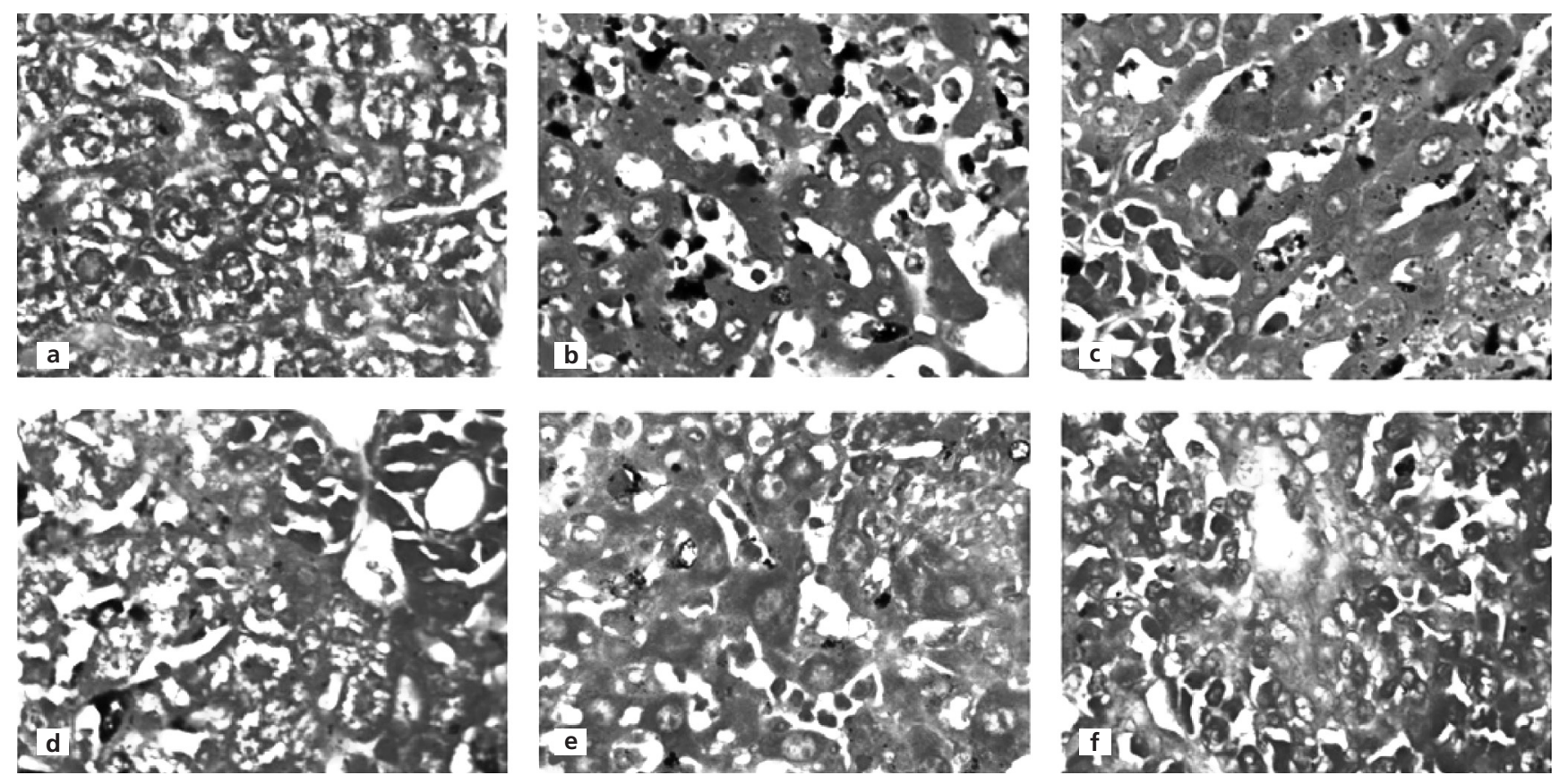

Figure 7. Photomicrographs of the liver with Giemsa stain (×1000). Negative control (a), Positive control (b), $50 \mathrm{mg} / \mathrm{kg} \mathrm{Ml} \mathrm{(c),} 100 \mathrm{mg} / \mathrm{kg} \mathrm{Ml} \mathrm{(d),}$ $150 \mathrm{mg} / \mathrm{kg} \mathrm{MI}(\mathbf{e})$, and artesunate (f). Black spots - Hemozoins (malarial pigments) found within the sinusoids and the cytoplasm of Kupffer cells.

sesses dual antimalarial activity as inhibitor of erythrocytic and liver stages of Plasmodium infections. ${ }^{[29]}$ Artesunate reduced the number of PRBCs in circulation and this was in accordance witha previous study by Georgewill and Ebong. ${ }^{[30]}$

The photomicrographs of this study revealed that the histoarchitecture of the liver in negative control appeared normal with radially channeled sinusoids towards the central vein. There were few Kupffer cells within the sinusoids and the endothelium of the central vein was clearly distinctive from the membranes of the hepatocytes surrounding it. There was also no endemic inflammation of hepatocytes. The hepatocytes were normal, and were positioned wall-to-wall and membrane-to-membrane with one another with sinusoids between them. Hepatic dysfunction in severe malaria infection was due to failure of bilirubin excretion from heavy parasitemia, ischemia and acidosis. ${ }^{[31]}$ In the positive control group, liver changes in severe malaria cases such as hyperplastic Kupffer cells ${ }^{[16]}$ were observed in this study. Portal tract inflammation was revealed by the presence of inflammatory lymphocytes surrounding the portal triad, as previously reported by Chawla et al. ${ }^{[17]}$ In our study, there was derangement in the radial channeling of the sinusoids towards the portal vein in accordance to the study of Rupani and Amarapurkar. ${ }^{[15]}$ This was evident in the positive control, $50 \mathrm{mg} / \mathrm{kg} \mathrm{MI}$ and $100 \mathrm{mg} / \mathrm{kg}$ MI groups. In the positive control group, there was disturbance in the pattern of sinusoid arrangement and there appeared hyperplastic Kupffer cells and inflammatory lymphocytes. The group that received artesunate had hyperplastic Kupffer cells and portal tract inflammation similar to that in the report by Hamman et al. ${ }^{[32]}$ The MI extract presented a dose dependent reduction in inflammatory lymphocytes.

The regular distribution of the reticular fibers around the hepatocytes and the portal veins in the negative control group provides meshwork that gives mechanical support to the hepatic tissue. These fibers were observed in the negative control group, and appeared sparsely distributed in the positive control group. Gradual distribution of the reticular fibers was observed in the groups administered with MI in a dose dependent manner. This ameliorative impact of MI may be due to the presence of mangiferin which according to Rasool et al., ${ }^{[3]}$ has the ability to reverse the structural components of the liver. In the negative control, there was moderate distribution of collagen fibers around the portal vein which maintained the integrity of the vessels. Excess of these fibers may lead to fibrosis of the hepatic tissues. Increased distribution of collagen fibers was observed around the portal triad in the positive control group which may be due to hepatic toxicity parallel to the study of Rojkind et al. ${ }^{[34]}$ Reduced distribution of collagen fibers was evident in the groups administered with MI in a dose dependent pattern. This reduc- 
tion in the distribution of collagen fibers may be due to ability of quercetin, one of the most abundant flavonoids in MI, in preventing the development of hepatic fibrosis by reducing type I collagen mRNA production in liver tissue. ${ }^{[3]]}$ It was also reported by Yuan et al ${ }^{[36]}$ that flavonoids were able to ameliorate liver injury and protect rats from CCl4-induced liver fibrosis by suppressing oxidative stress.

Our results for the Kupffer cell density showed increased distribution of Kupffer cells within the sinusoids of the positive control group which shows the response to the damage caused by the parasite congestion and breakdown of ruptured red blood cells by phagocyte action. Hyperplastic Kupffer cells were evident in the positive control group and there was a reduction in the distribution of the Kupffer cells in a dose dependent manner. The increase in Kupffer cell numbers with more lymphocytic infiltration in the portal spaces is a prominent response of body facing any injurious impact. ${ }^{[37]}$ Dharmeshkumer et al. ${ }^{[3]}$ reported severe hepatic dysfunction during maximum parasitemia where the liver was enlarged with more sinusoidal dilatation and hyperplasia of Kupffer cells.

There was densely-packed $\mathrm{Hz}$ in the positive control group when compared with other groups. The density of these $\mathrm{Hz}$ was reduced in the extract and artesunate treated groups, and this reduction was also dose-dependent. The reduction may be due to reduction of PRBCs present in circulation. It was evident that the $\mathrm{Hz}$ distribution in artesunate group was similar to the group that was administered $150 \mathrm{mg} / \mathrm{kg} \mathrm{MI}$. $\mathrm{Hz}$ is a disposal product formed from the digestion of red blood cells by malaria parasites, and it was observed in the cytoplasm or outside the Kupffer cells as black or brownish granule. ${ }^{[39]}$

\section{Conclusion}

This study shows that Mangifera indica has an ameliorating effect against injury to liver histoarchitecture, and also reveals that it is capable of ameliorating the hepatic disruptions such as loss of reticular fibers and the distribution of collagen fibers. Also, there was a dose dependent significant reduction in the percentage of parasitemia level and Kupffer cell density in the extract treated groups as compared with the positive control group.

\section{Acknowledgment}

We acknowledge the technical inputs of R. A. Bejide, of the Department of Morbid Anatomy and Forensic Medicine, during the histological procedures.

\section{References}

1. Nicholas JW, Breman JG. Malaria and babeiosis; diseases caused by red blood cell parasites. In: Kasper DL, Braunwald E, Hauser S, Longo D, Jameson JL, Fauci AS, editors. Harrison's principles of internal medicine. 16th ed. New York: McGraw Hill; 2005. p. 1218.

2. World Health Organization. Malaria chemotherapy. WHO technical report series. Geneva: WHO; 1998. 1998.

3. Palmer J. WHO gives indoor use of DDT a clean bill of health for controlling malaria. Indian J Med Sci 2006;60:439-41.

4. Hall N, Karras M, Raine JD, Carlton JM, Kooij TW, Berriman M, Florens L, Janssen CS, Pain A, Christophides GK, James K, Rutherford K, Harris B, Harris D, Churcher C, Quail MA, Ormond D, Doggett J, Trueman HE, Mendoza J, Bidwell SL, Rajandream MA, Carucci DJ, Yates JR 3rd, KafatosFC, Janse CJ, Barrell B, Turner CM, Waters AP, Sinden RE. A comprehensive survey of the Plasmodium life cycle by genomic, transcriptomic, and proteomic analyses. Science 2005;307:82-6.

5. Kooij TW, Janse CJ, Waters AP. Plasmodium post-genomics: better the bug you know? Nat Rev Microbiol 2006;4:344-57.

6. Good MF. The hope but challenge for developing a vaccine that might control malaria. Eur J Immunol 2009;39:939-43.

7. World Health Organization. Guidelines for the treatment of malaria. 3rd ed. Geneva: WHO; 1998. 316 p.

8. Dondorp AM, Desakorn V, Pongtavornpinyo W, Sahassananda D, Silamut K, Chotivanich K, Newton PN, Pitisuttithum P, Smithyman AM, White NJ, Day NP. Estimation of the total parasite biomass in acute falciparum malaria from plasma PfHRP2. PLoS Med 2005;2:e204.

9. Bartoloni A, Zammarchi L. Clinical aspects of uncomplicated and severe malaria. Mediterr J Hematol Infect Dis 2012;4:e2012026.

10. Nadjm B, Behrens RH. Malaria: an update for physicians. Infect Dis Clin North Am 2012;26:243-59.

11. World Health Organization. Malaria chemoprophylaxis: problems associated with the chemoprophylaxis of travellers to endemic areas. Wkly Epidemiol Rec 1986;61:109-16.

12. Cook GC. Plasmodium falciparum infection: problems in prophylaxis and treatment in 1986. Q J Med 1986;61:1091-115.

13. Pillay VV. Modern medical toxicology. 4th ed. New Delhi: Jaypee Publishers; 2013. 460 p.

14. Rouveix B, Bernard J, Michon C. Mefloquine and anacute brain syndrome. Ann Intern Med 1989;110:577-8.

15. Rupani AB, Amarapurkar AD. Hepatic changes in fatal malaria: an emergingproblem. Ann Trop Med Parasitol 2009;103:119-27.

16. Whitten R, Milner DA Jr, Yeh MM, Kamiza S, Molyneux ME, Taylor TE. Liver pathology in Malawian children with fatal encephalopathy. Hum Pathol 2011;42:1230-9.

17. ChawlaLS, Sidhu G, Sabharwal BD, Bhatia K, Lsood A. Jaundice in Plasmodium falciparum malaria. J Assoc Physicians India 1989; $37: 390-2$.

18. Srivastava HC, Sharma SK, Bhatt RM, Sharma VP. Studies on Plasmodium vivax relapse pattern in Kheda district, Gujarat. Indian J Malariol 1996;33:173-9.

19. Viriyavejakul P, Khachonsaksumet V, Punsawad C. Liver changes in severe Plasmodium falciparum malaria: histopathology, apoptosis and nuclear factor kappa B expression. Malar J 2014;13:106. 
20. Rungruang T, Kaewkongkwan Y, Sukakul T, Kettawan A, Chompoopong S, Boonmars T. The effect of vitamin $\mathrm{C}$ on morphology and histology of liver and spleen of Plasmodium-infected mice. International Food Research Journal 2013;20:1639-43.

21. Ross IA. Medicinal plants of the world. Vol 1. Clifton (NJ): Humana Press; 1999. p. 199-202.

22. Scartezzini P, Speroni E. Review on some plants of Indian traditional medicinewith antioxidant activity. J Ethnopharmacol 2000; 71:23-43.

23. Oyewo OO, Onyije FM, Ashamu EA, Akintunde OW, Ayeni OJ. Evaluation of aqueous stem bark extract of Mangifera indica on the liver of Wistar rats. Asian Journal of Pharmaceutical and Biological Research 2012; 2:231-3.

24. Basir R, Rahiman SF, Hasballah K, Chong W, Talib H, Yam M, Jabbarzare M, TieT, Othman F, Moklas M, Abdullah W, Ahmad Z. Plasmodium berghei ANKA Infection in ICR mice as a model of cerebral malaria. Iran J Parasitol 2012;7:62-74.

25. Yeshanew S, Mekonnen Y. The effect of Otostegia integrefolia leaf extracts on the packed cell volume, body weight and survival time of Plasmodium berghei infected mice. International Journal of Tropical Medicine2013;8:129-34.

26. Perlmann P, Troye-Blomberg M, editors. Malaria immunology. 2nd ed. Basel: Karger; 2002.

27. Nwinuka NM, Monanu MO, Nwiloh BI. Effects of aqueous extract of Mangifera indica L. (Mango) stem bark on haemoatological parameters of normal albino rats. Pakistan Journal of Nutrition 2008; 7:663-8.

28. Sellamuthu PS, Muniappan BP, Perumal SM, Kandasamy M. Antihyperglycemic effect of mangiferin in streptozotocin induced diabetic rats. Journal of Health Sciences 2009;55:206-14.

29. Ramalhete C, da Cruz FP, Mulhovo S, Sousa IJ, Fernandes MX, Prudencio M, Ferreira MJU. Dual-stage triterpenoids from an African medicinal plant targeting the malaria parasite. Bioorg Med Chem 2014;22:3887-90.
30. Georgewill UO, Ebong OO. A comparative study on the efficacy of some artemisinin combination therapies on Plasmodium berghei in Swiss albino mice. Pharmacol Pharm 2012;3:109-12.

31. Bhalla A, Suri V, Singh V. Malarial hepatopathy. J Postgrad Med 2006;52:315-20.

32. Hamman WO, Musa SA, Muzaffar F, Sani SO, Umana UE, Timbual JA, Nok AJ, Ojo SA. Acute exposure to artesunate and its effect on the hematological indices, hepatotoxicity and histology of the liver of adult wistar rats. Asian Journal of Medical Sciences 2011;3:176-9.

33. Rasool M, Sabina EP, Mahinda PS, Gnanselvi BC. Mangiferin, a natural polyphenol protects the hepatic damage in mice caused by CCl4 intoxication. Comp Clin Path 2012;21:865- 72.

34. Rojkind M, Giambrone MA, Biempica L. Collagen types in normal and cirrhoticliver. Gastroenterology 1979;76:710-9.

35. Lee ES, Lee HE, Shin JY, Yoon S, Moon JO. The flavonoids quercetin inhibits dimethylnitrosamine-induced liver damage in rats. J Pharm Pharmacol 2003;55:1169-74.

36. Yuan LP, Chen FH, Ling L, Bo H, Chen ZW, Li F, Zhong MM, Xia LJ. Protective effects of total flavonoids of Biden bipinnata L. against carbon tetrachloride-induced liver fibrosis in rats. J Pharm Pharmacol 2008;60:1393-402.

37. Miura S, Suematsu M, Tanaka S, Nagata H, Houzawa S, Suzuki M, Kurose I, Serizawa H, Tsuchiya M. Microcirculatory disturbance in indomethacin-inducedintestinal ulcer. Am J Physiol 1991; 261:G213-9.

38. Dharmeshkumar NP, Pradeep P, Surti MM, Agarwal SB. Clinical manifestation of complicated malaria an overview. Journal of Indian Academy of Clinical Medicine 2003;4:323-31.

39. Soniran OT, Idowu OA, Ajayi OL, Olubi IC. Comparative study on the effects of chloroquine and artesunate on histopathological damages caused by Plasmodium berghei in four vital organs of infected albino mice. Malar Res Treat 2012;2012:960758.

Correspondence to: Ahmed A. Olayode, B.SC, M.SC Department of Anatomy and Cell Biology, Faculty of Basic Medical Sciences, Obafemi Awolowo University, Ile-Ife, Osun State, Nigeria Phone: +234 8057077587 e-mail: olayodeahmed01@gmail.com

Conflict of interest statement: No conflicts declared.

This is an open access article distributed under the terms of the Creative Commons Attribution-NonCommercial-NoDerivs 3.0 Unported (CC BY-NCND3.0) Licence (http://creativecommons.org/licenses/by-nc-nd/3.0/) which permits unrestricted noncommercial use, distribution, and reproduction in any medium, provided the original work is properly cited. Please cite this article as: Olayode AA, Ofusori DA, Ogunniyi TAB, Saka OS. Histomorphological studies of the liver of Plasmodium-infected albino mice after administration of aqueous leaf extract of Mangifera indica (Linn.). Anatomy 2015;9(3):168-176. 